\title{
ANALISIS PEMBUBARAN ORGANISASI KEMASYARAKATAN HIZBUT TAHRIR INDONESIA DALAM PERSPEKTIF NEGARA HUKUM YANG BEBAS BERSERIKAT
}

\author{
Aini Kusuma Wardani ${ }^{1 \bowtie}$ \\ ${ }^{1}$ Magister Hukum, Fakultas Hukum Universitas Sebelas Maret, Surakarta, Indonesia \\ Jln. Ir. Sutami, No. 36A, Surakarta, Jawa Tengah 57126- Phone 0271-642595 \\ $\triangle$ Ainikusuma11@gmail.com
}

\begin{abstract}
The results of the study of this article concluded that the 1945 National Constitution emphasized the importance of the system of check and balances (supervision and balance) which need to be a clear division of power between executive and judicial functions. This means that in the problem of dissolving community organizations it is very important to involve the court to break the verdict of the dissolution of community organizations in Indonesia by carrying out the settlement of disputes in court using the principle of justice, simple and mild costs so that the process of resolving the dissolution of community organizations can be carried out effectively and effectively.
\end{abstract}

Keywords: Community organization, HTI

Berdasarkan hasil kajian artikel ini menyimpulkan bahwa UUD NRI Tahun 1945 menekankan pentingnya sistem check and balances (pengawasan dan keseimbangan) yang mana perlu ada pembagian kekuasaan yang jelas antara fungsi eksekutif dan yudikatif. Artinya dalam permasalahan pembubaran organisasi kemasyarakatan sangat penting untuk melibatkan pengadilan untuk memutus vonis pembubaran organisasi kemasyarakatan di Indonesia dengan cara melakukan penataan penyelesaian sengketa di pengadilan dengan menggunakan asas peradilan cepat, sederhana dan biaya ringan sehingga proses penyelesaian sengketa pembubaran organisasi kemasyarakatan bisa dilaksanakan secara efektif dan efisien.

Kata Kunci: Organisasi Kemasyarakatan, HTI 


\section{INTRODUCTION}

Organisasi kemasyarakatan yang selanjutnya disingkat (ormas) merupakan peran serta masyarakat dalam melaksanakan pembangunan untuk memajukan kehidupan yang berkeadilan dan kemakmuran. ${ }^{1}$ Keberadaan organisasi kemasyarakatan di Indonesia sebenarnya sudah terbentuk semenjak awal abad ini dan mempunyai kedudukan paling strategis bagi proses kebangsaan Indonesia. Bahkan sebagian dari organisasi kemasyarakatan tersebut akhirnya menjadi partai politik yang mempelopori gerakan kebangsaan. ${ }^{2}$

Dinamika perkembangan organisasi kemasyarakatan dan perubahan sistem pemerintahan membawa paradigma baru dalam tata kelola organisasi kemasyarakatan dalam kehidupan bermasyarakat, berbangsa, dan bernegara. Pertumbuhan jumlah organisasi kemasyarakatan, sebaran dan jenis kegiatan organisasi kemasyarakatan dalam kehidupan demokrasi makin menuntut peran, fungsi dan tanggung jawab organisasi kemasyarakatan untuk berpartisipasi dalam upaya mewujudkan cita-cita nasional bangsa Indonesia, serta menjaga dan memelihara keutuhan dan kedaulatan Negara Kesatuan Republik Indonesia. Peningkatan peran dan fungsi organisasi kemasyarakatan dalam pembangunan memberi konsekuensi pentingnya membangun sistem pengelolaan organisasi kemasyarakatan yang memenuhi kaidah organisasi kemasyarakatan yang sehat sebagai organisasi nirlaba yang demokratis, profesional, mandiri, transparan, dan akuntabel. Oleh karena itu, dinamika organisasi kemasyarakatan dengan segala kompleksitasnya menuntut pengelolaan dan pengaturan hukum yang lebih komprehensif melalui undang-undang. ${ }^{3}$

Kebebasan berserikat dan berkumpul merupakan salah satu hak kunci (key right) dalam HAM, karena dengan kebebasan tersebut manusia dapat menikmati hak dan kebebasan lainnya yang ditetapkan oleh hukum. Meskipun demikian, kebebasan tersebut bukan merupakan hak yang absolut, artinya kebebasan tersebut tunduk kepada sejumlah pembatasan yang juga harus ditetapkan dalam undang-undang. Hal ini bukan saja merupakan cerminan, melainkan prasyarat dalam sebuah negara demokrasi. Pembatasan tersebut diperlukan apabila adanya kepentingan untuk melindungi keamanan nasional atau keselamatan publik (national security or public safety), ketertiban umum (public order), perlindungan kesehatan dan moralitas publik (public health or morals), dan perlindungan terhadap hak dan kebebasan pihak lain. ${ }^{4}$

Menurut Hans Kelsen bahwa salah satu esensi demokrasi terletak pada ada tidaknya sebuah kompromi yang menyatukan perbedaan pendapat untuk menentukan sebuah tatanan bagi landasan sebuah negara. Kompromi menjadi sebuah syarat utama dalam penentuan apakah sebuah negara menganut prinsip demokrasi ataukah tidak sama sekali.

1 Sara Hersriavita, 'UPAYA PENGEMBALIAN KERUGIAN NEGARA DARI PERKARA TINDAK PIDANA KORUPSI OLEH KEJAKSAAN NEGERI SUKOHARJO', Jurnal Hukum Dan Pembangunan Ekonomi, 7.1 (2019), 15-28.

2 Wijiatmo and Supanto, 'Kebijakan Hukum Pidana Dalam Memberikan Perlindungan Hukum Terhadap Guru Dalam Hal Kedisplinan', Pasca Sarjana Hukum UNS, VII No 1 J (2019), 85-92.

${ }^{3}$ Farid Achmad, 'Urgensi Penguatan Peran Penuntut Umum Dalam Sistem Peradilan Pidana Indonesia', Jurnal Pasca Sarjana Hukum UNS, VII.1 (2019), 1-14.

4 Adi Sulistiyono, 'Majelis Kehormatan Disiplin Kedokteran Indonesia ( Mkdki) Untuk Dapat Menjamin Keadilan Dalam Hubungan Dokter Dan Pasien’, Jurnal Pasca Sarjana Hukum UNS, VII.1 (2019), 29-38. 
Ada sebuah pegangan dalam memahahi negara dengan bercirikan prinsip demokras antara lain: ${ }^{5}$

1) Adanya kehendak mayoritas dan kehendak minoritas.

2) Kehendak mayoritas tidak bisa menjadi dominasi absolut.

3) Adanya kompromi di antara kehendak mayoritas dengan kehendak minoritas dalam menyikapi sebuah permasalahan dan dalam pembentukan sebuah tatatan.

4) Tidak ada pemaksaan dalam beragama dan berkeyakinan.

5) Terdapat kebebasan berbicara, kebebasan pers, dan pendapat untuk mengemukakan pendapat dijamin keberadaannya, baik melalui konstitusi ataupun melalui kesepakatan adat yang terjadi di sebuah negara.

6) Kompromi yang sehat menjadikan tidak diketemukannya perbenturan kepentingan antara kehendak mayoritas dan kehendak minoritas yang akan biasanya akan berbuah pada anarki.

Pasca Reformasi, posisi dan peran organisasi kemasyarakatan tampak bergeser. Euforia Reformasi dan demokratisasi Pasca Reformasi membuat organisasi kemasyarakatan kembali terpolarisasi dalam arus ideologi dan politik. Pasca Reformasi juga ditandai dengan menjamurnya ribuan organisasi kemasyarakatan baru. Kategori dan definisi organisasi kemasyarakatan pada era ini juga semakin berkembang luas dengan beragam persilangan arus kepentingan politik dan ideologi baik dalam skala nasional dan internasional. Keberadaan. Negara/Pemerintah Pasca Reformasi seringkali terjebak dalam posisi yang saling behadap-hadapan karena dua faktor utama. Pertama, rendahnya kepercayaan sebagian pemimpin Ormas tertentu pada Negara/Pemerintah. Kedua, masih dijumpai adanya kesalahpahaman atas peran Negara/Pemerintah dihadapan para pendukung Ormas. ${ }^{6}$

Selain fenomena tersebut, Pasca Reformasi juga ditandai adanya tindakan kekerasan dan anarkisme yang dilakukan Ormas tertentu. Obyek anarkisme ini tidak lagi sematamata pada sejumlah kantor Pemerintahan. Aksi anarkisme Ormas juga ditujukan pada institusi media massa. Tidak hanya itu aksi anarkisme dan kekerasan juga terjadi antar para pendukung Ormas. Akar penyebab adanya tindakan anarkisme dan kekerasan ini adakalanya tidak hanya sebatas pada kepentingan politik yang bersifat jangka pendek. Lebih dari itu, konflik antar Ormas seringkali bersumber dari akar konflik yang bersifat laten, yaitu adanya pertentangan landasan ideologi yang mereka yakini.Pasca Reformasi, tampak masih terbuka potensi besar dimana perbedaan landasan ideologi yang dianut oleh masing-masing Ormas justru kian mendegradasi imaji ke-Indonesia-an. Anarkisme yang dilakukan oleh Ormas tertentu ini tentu sangat kontras dengan keberadaan Ormas masa Pra Kemerdekaan dimana mereka secara kolektif menyemaikan benih Nasionalisme dan ke-Indonesia-an. Dinamika Ormas yang demikian tentu jauh dari yang diharapkan. ${ }^{7}$

\footnotetext{
${ }^{5}$ Ahmad Kodir Jailani Tanjung, Hari Purwadi, and Hartiwiningsih, 'Paradigma Hakim Dalam Memutuskan Perkara Pidana Di Indonesia', Jurnal Pasca Sarjana Hukum UNS, 7.1 (2019), 39-51 <https://jurnal.uns.ac.id/hpe/article/view/29178>.

${ }_{6}$ Yulianus Dica and others, 'Pengendalian Peredaran Minuman Beralkohol Dalam Wilayah Hukum Polres Boyolali', VII (2019), 120-33.

7 Suprianto, Agus Riwanto, and Sunny Ummul Firdaus, 'Implementasi Peraturan Pemerintah Nomor 18 Tahun 2016 Tentang Perangkat Daerah Terhadap Efektivitas Kinerja Pegawai Sekretariat Daerah Dewan Perwakilan', Jurnal Pasca Sarjana Hukum UNS, VII.1 (2019), 134-43.
} 
Eksistensi organisasi kemasyarakatan pada masa kini harus mampu membawa dan memperjuangkan aspirasi dan kehendak masyarakat sebagai medium untuk melaksanakan kegiatan yang edukatif dan bernilai sehingga bermanfaat demi kepentingan bersama yang sejalan dengan amanat Pancasila. Walaupun kodrat sebuah organisasi memiliki pasangsurut dalam menjalankan roda organisasinya, namun semua itu merupakan dinamika yang terus mewarnai kehidupan organisasi kemasyarakatan untuk terus berbuat dan bertindak atas nama kehendak rakyat dan UUD NRI Tahun $1945 .{ }^{\circ}$

Indonesia yang telah meneguhkan diri menjadi negara hukum yang demokratis merupakan hal yang wajar apabila tiap tahun bermunculan banyak organisasi-organisasi baru, karena konsekuensi logis dari sebuah negara hukum demokratis menghendaki adanya kebebasan dalam mengeluarkan pendapat, berserikat, dan berkumpul sehingga semakin banyak masyarakat yang ingin mendirikan organisasi sebagai wadah untuk mengembangkan potensi kekuatan yang mereka miliki dalam rangka turut serta membangun peradaban bangsa. Meningkatnya jumlah organisasi kemasyarakatan yang ada paling tidak selaras dengan prinsip-prinsip saling menghormati dan menghargai kebebasan orang lain sepanjang kebebasan tersebut tidak bertentangan dengan peraturan perundangundangan. Hal ini sangat penting guna menyuburkan kesadaran terhadap pentingnya perjuangan melalui lembaga sehingga masyarakat akan semakin selektif dalam memilih dan berafiliasi dengan organisasi yang memiliki kesamaan ideologi. ${ }^{9}$

Permasalahannya adalah belakangan ini munculnya gerakan-gerakan beberapa organisasi kemasyarakatan yang bertindak dengan kekerasan dan anarkis. Tindakan kekerasan ini seringkali dipicu oleh ego sentris kelompok dengan dalih bahwa hukum sudah tidak berjalan secara mekanis lagi, sehingga dengan mandeknya mekanisme hukum itu banyak dari mereka mengambil jalan sendiri dengan melakukan penindakan nonhukum yang secara jelas melanggar norma hukum. Justru tanpa disadari sesungguhnya tindakan tersebut merupakan perbuatan melawan hukum dan bertentangan dengan Pancasila. ${ }^{10}$

Organisasi kemasyarakatan merupakan entitas dari kebebasan berserikat, berkumpul dan berpendapat yang dijamin dalam Undang- Undang Dasar Negara Republik Indonesia Tahun 1945. Jaminan yang diberikan oleh konstitusi tersebut semestinya menjadi instrumen untuk melaksanakan hak dan kewajibannya secara konstitusional dengan memperhatikan kondisi sosial yang aman dalam mengekspresikan kebebasannya dihadapan publik. Patut disadari bahwa ternyata kebebasan tersebut seringkali digunakan tanpa kendali dan tanpa batas yang mana prinsip-prinsip saling menghargai dan menghormati kebebasan orang lain tidak lagi dipatuhi sehingga menimbulkan ketidakstabilan sosial dalam kehidupan berbangsa dan bernegara. Celakanya, tindakan anarkis seolah-seolah dilegitimasi atas nama negara dan agama yang

8 Hernindyo Reinan Mahastoro and others, 'PERTANGGUNGJAWABAN HUKUM PENGURUS YAYASAN TERHADAP RUMAH SAKIT YANG DIKELOLA OLEH YAYASAN', VII (2019), 212-18.

${ }^{9}$ Mahastoro and others.

${ }^{10} \mathrm{~N}$ W Afreeportamara, 'Hambatan Kurator Dalam Menyelesaikan Piutang Koperasi Yang Diputus Pailit', Jurnal Hukum Dan Pembangunan Ekonomi, 243-50 <https://jurnal.uns.ac.id/hpe/article/view/43014>. 
seyogyanya tidak patut dilakukan karena tidak sejalan dengan nafas hidup negara hukum yang demokratis. ${ }^{11}$

Melihat kondisi rill tersebut, justru sangat merugikan dan tidak baik dipertontonkan kepada publik. Apalagi organisasi kemasyarakatan yang tidak pernah berhenti melakukan tindakantindakan kekerasan dan anarkis menimbulkan ketidakpercayaan publik terhadap eksistensi organisasi kemasyarakatan dalam memperjuangkan aspirasi masyarakat. Keadaan inilah yang mendorong pemerintah untuk bertindak sesuai prosedur hukum yang berlaku guna memastikan keamanan masyarakat berjalan dengan baik. ${ }^{12}$

Ketentuan Undang-Undang Nomor 16 Tahun 2017 memberikan kewenangan kepada pemerintah untuk memberikan sanksi tegas kepada organisasi kemasyarakatan. hukuman yang paling berat diterima oleh organisasi kemasyarakatan yang bermasalah adalah pencabutan legalisasi dari negara yang secara otomatis organisasi kemasyarakatan bubar dengan sendirinya. ${ }^{13}$

Problematika pembubaran organisasi kemasyarakatan ini ada dikarenakan maraknya paham anti Pancasila dan radikalisme yang justru berkembang bebas di Indonesia. Tercatat bahwa dalam Pemerintah Republik Indonesia sebelumnya telah terdapat beberapa Organisasi Kemasyarakatan yang dipandang telah melanggar spirit dan nilai-nilai Pancasila dan Konstitusi Undang Undang Dasar Negara Republik Indonesia Tahun 1945, salah satunya ialah Hizbut Tahrir Indonesia. ${ }^{14}$

Secara ideologis, HTI merupakan organisasi Partai Politik Islam yang berdiri pada tahun 1953 di Timur Tengah, tepatnya di Negara Yordania. Saat ini HTI sudah memiliki cabang di hamper 30 negara termasuk Indonesia. Namun di Indonesia HTI mewujud sebagai ormas yang berjuang di luar sistem politik Negara untuk menegakkan syari'at Islam di bawah naungan daulah khilafah, suatu sistem pemerintahan yang dipimpin seorang khalifah. ${ }^{15}$

Salah satu alasan mendirikan Negara khilafah menurut HTI adalah bahwa sistem politik demokrasi merupakan representasi dari ideologi sekulerisme dan kapitalisme. Mereka juga memandang demokrasi bukan hanya sebagai ideologi tetapi sebagai al at penjajahan negaranegara barat terutama Amerika untuk menjajah negara-negara yang berpenduduk Muslim. Dengan demikian, demokrasi harus ditolak dan diganti dengan ideologi Islam. Untuk mewujudkan ideologinya tersebut, HTI menempuh dua strategi perlawanan terhadap dunia barat, yaitu: (1) perlawanan pemikiran, (2) perlawanan politik. ${ }^{16}$

11 Agus Riwanto Bahar Elfudllatsani, Isharyanto, 'Kajian Mengenai Kebebasan Berkumpul Dan Berserikat Organisasi Kemasyarakatan Kaitannya Dengan Teori Kedaulatan Rakyat Dan Hak Asasi Manusia', Jurnal Pasca Sarjana Hukum UNS, VII.1 (2019), 52-61.

12 Agung Ariyanto and others, 'Politik Hukum Asas Non-Legally Binding Rekomendasi Ombudsman Republik Indonesia Sebagai Instrumen Pencegahan Dan Penanganan Laporan Maladministrasi', Jurnal Pasca Sarjana Hukum UNS, VII (2019), 62-73.

${ }_{13}$ Ariyanto and others.

14 Satriawan Sulaksono, 'KORBAN TINDAK PIDANA PENCUCIAN UANG YANG TERCAMPUR DENGAN ASET PELAKU ’”, 107-19.

${ }^{15}$ Edi Warsito, 'Balai Konservasi Sumber Daya Alam Yogyakarta', Pasca Sarjana Hukum UNS, VII.1 (2019), 153-68<https://jurnal.uns.ac.id/hpe/article/view/29210>.

${ }^{16}$ Warsito Bayu Rangga and Albertus Sentot Sudarwanto, 'Penyelesaian Kredit Macet Dengan Agunan Yang Diambil Alih (AYDA) Sebagai Upaya Perlindungan Kreditur Di Perseroan Daerah BPR Bank Klaten', Jurnal Pasca Sarjana Hukum UNS, VII.2 (2019), 187-95 < https://digilib.uns.ac.id/dokumen/detail/77603/Penyelesaian-Kredit- 
Sesuai dengan namanya, Hizbut Tahrir artinya adalah Partai Pembebasan. Dalam laman resmi Hizbut Tahrir, disebutkan bahwa organisasi ini adalah partai politik, bukan organisasi kerohanian, bukan lembaga pendidikan, dan bukan pula lembaga sosial (yang bergerak di bidang sosial kemasyarakatan). Jika ditelusuri, HTI di Kementrian Dalam Negeri HTI tercatat sebagai organisasi kemasyarakatan sejak tahun 2000.

HTI dikenal sebagai organisasi yang unik karena mempunyai mengembalikan kehidupan Islami dengan menerapkan syariat Islam sebagai aturan kehidupan. Daya tarik dari HTI, lain dari yang lain karena gencar memaparkan solusi Islam secara runtut dan sistematis tanpa basa-basi untuk mengatasi segala macam problematika umat Islam khususnya di Indonesia. Segala macam problematika manusia itu dengan gamblang dipaparkan dan dijawab oleh HTI sehingga siapapun bisa merespon solusi Syariah dan Khilafah dalam perspektif HTI baik dilihat dari segi ilmiah maupun segi keimanan atau akidah. Namun demikian, apapun bentuk dan tujuan yang diusung oleh HTI, jelas-jelas bahwa ormas ini dapat mengancam kerukunan umat beragama di Indonesia. Di beberapa negara Timur Tengah sendiri, Hizbut Tahrir masuk dalam daftar organisasi terlarang. ${ }^{17}$

Menyikapi fenonema tersebut, muncul desakan dari berbagai pihak agar pemerintah perlu segera mengambil langkah hukum secara tegas dan segera membubarkan keberadaan Ormas HTI. Dalam rangka menyerap aspirasi dari masyarakat tersebut, akhirnya Pemerintah Indonesia melalui suatu proses pengkajian yang panjang, melalui Menteri Koordinator bidang Politik, Hukum dan Keamanan, Wiranto, pada tanggal 8 Mei 2017, Ormas HTI dilarang eksistensinya di Indonesia. Beberapa alasan pembubaran HTI yang dikemukakan oleh pemerintah, diantaranya adalah sebagai berikut:

a. Sebagai ormas berbadan hukum, HTI tidak melaksanakan peran positif untuk mengambil bagian dalam proses pembangunan guna mencapai tujuan nasional.

b. Kegiatan yang dilaksanakan oleh HTI terindikasi kuat telah bertentangan dengan tujuan, azas, dan ciri yang berdasarkan Pancasila dan UUD Negara Republik Indonesia tahun 1945 sebagaimana diatur dalam Undang-Undang No. 17 Tahun 2013 tentang Ormas.

c. Aktifitas yang dilakukan oleh HTI dinilai telah menimbulkan benturan di masyarakat yang dapat mengancam keamanan dan ketertiban masyarakat, serta membahayakan keutuhan NKRI.

Sebagai tindak lanjut dari pembubaran tersebut, Kementrian Hukum dan HAM (Kemenkum HAM) melalui Direktur Jenderal Administrasi Hukum Umum, kemudian resmi mencabut Surat Ketetapan (SK) Badan Hukum HTI terhitung mulai tanggal 19 Juli 2017. Sebelumnya, HTI tercatat di Kemenkum HAM sebagai Badan Hukum Perkumpulan dengan nomor registrasi AHU00282.60.10.2014 pada 2 Juli 2014. Adapun HTI pada saat mengajukan permohonan Badan Hukum Perkumpulan melakukan secara elektronik atau melalui website http://www.ahu.go.id. Keputusan pencabutan SK Putusan yang diambil oleh Kemenkum HAM tersebut adalah mendasarkan kepada Peraturan Pemerintah Pengganti Undang-undang (Perppu) No. 2 Tahun 2017 tentang

Macet-dengan-Agunan-yang-Diambil-Alih-AYDA-sebagai-Upaya-Perlindungan-Kreditur-di-Perseroan-Daerah-BPRBank-Klaten>.

${ }^{17}$ Warsito Bayu Rangga and Albertus Sentot Sudarwanto. 
Perubahan Undang-undang No. 17 Tahun 2013 tentang Organisasi Kemasyarakatan yang disahkan pada tangal 10 Juli 2017.

Menyikapi keputusan pemerintah tentang pembubarannya tersebut, pihak HTI pun tinggal diam. Melalui kuasa hukumnya Yusril Ihza Mahendra, pada tanggal 18 Juli 2017 pihak HTI mengajukan uji formil dan uji materil terhadap Perpu No. 2 Tahun 2017 tentang Organisasi Masyarakat kepada Mahkamah Konstitusi (MK). Bahkan pada tanggal 13 Oktober 2017, pihak HTI menggugat Menteri Hukum dan Hak Asasi Manusia dan Direktur Jendral Administrasi Hukum Umum ke Pengadilan Tata Usaha Negara (PTUN). Dalam gugatannya, HTI meminta agar SK Nomor AHU30.A.01.08 Tahun 2017 tentang Pencabutan Status Hukum ormas tersebut dibatalkan. Walaupun demikian, dalam prakteknya upaya hukum yang dilakukan oleh pihak HTI pun mengalami jalan buntu, karena baik gugatan uji formil maupun uji materil yang dilakukan ke MK serta gugatan yang dilakukan ke PTUN kedua-duanya tetap ditolak oleh majelis hakim.

Dalam prakteknya, pembubaran ormas HTI tersebut dinilai oleh berbagai kalangan telah melanggar kebebasan berserikat sebagai warga negara. Hak atas kebebasan berserikat (right to freedom of association) merupakan hak fundamental. Hak atas kebebasan berserikat tersebut dengan lugas telah dijamin dalam Konstitusi, yakni Pasal 28 UUD 1945 dan Pasal 28E UUD 1945. Selain dalam konstitusi, hakikat mengenai hak atas kebebasan berserikat juga diatur dalam Pasal 24 UndangUndang No. 39 Tahun 1999 tentang Hak Asasi Manusia yang menyatakan bahwa: ${ }^{18}$

1) Setiap orang berhak untuk berkumpul, berapat, dan berserikat, untuk maksud-maksud damai.

2) Setiap warga negara atau kelompok masyarakat berhak mendirikan partai politik, lembaga swadaya masyarakat atau organisasi lainnya untuk berperan serta dalam jalannya pemerintahan dan penyelenggaraan negara sejalan dengan tuntutan perlindungan, penegakan dan pemajuan hak asasi manusia sesuai dengan ketentuan peraturan perundang-undangan.

Sedangkan dalam Deklarasi Universal Hak Asasi Manusia hak atas kebebasan berserikat dijamin dalam pasal 20 dengan menyatakan:

1) Setiap orang mempunyai hak atas kebebasan berkumpuldan berserikat tanpa kekerasan.

2) Tidak seorang pun boleh dipaksa untuk memasuki suatu perkumpulan.

\section{DISCUSSION}

\section{Pengaturan Pembubaran Organisasi Kemasyarakatan di Indonesia}

Asas organisasi kemasyarakatan yaitu tidak bertentangan dengan Pancasila dan Undang-Undang Dasar Negara Republik Indonesia Tahun 1945. Kemudian organisasi kemasyarakatan dapat mencantumkan ciri tertentu yang mencerminkan kehendak dan cita-cita organisasi kemasyarakatan yang tidak bertentangan dengan Pancasila dan Undang-Undang Dasar Negara Republik Indonesia Tahun 1945. Sedangkan dilihat dari

${ }^{18}$ Bahar Elfudllatsani, Isharyanto. 
sifatnya bahwa organisasi kemasyarakatan bersifat sukarela, sosial, mandiri, nirlaba, dan demokratis. ${ }^{19}$

Pasal tersebut bermakna bahwa dalam menjalankan ekspresi dan kebebasan sebuah organisasi kemasyarakatan harus berada pada jalur yang konstitusional berdasarkan cita-cita dan kehendak Pancasila dan Undang Undang Dasar Negara Republik Indonesia Tahun 1945. Memang harus disadari bahwa organisasi kemasyarakatan memiliki tujuan dan fungsi yang variatif, tetapi undangundang memberikan batasan kepada organisasi kemasyarakatan untuk bisa menjalankan tugasnya sebagai wadah perhimpunan yang memiliki nilai dan manfaat kepada masyarakat. begitupun dengan larangan-larangan yang diatur oleh UU sudah sangat jelas sebagai peringatan kepada organisasi kemasyarakatan agar tidak membuat pelanggaran yang berakibat pada pemberian sanksi kepada organisasi kemasyarakatan tersebut. Dengan demikian organisasi kemasyarakatan tidak dapat bertindak sewenangwenang maupun melakukan kekerasan/ perbuatan anarkis dengan mengatasnamakan kebenaran parsial yang dapat merugikan organisasi kemasyarakatan yang bersangkutan guna menjaga ketertiban serta ketentraman kehidupan berbangsa dan bernegara. ${ }^{20}$

Sanksi yang paling berat diberikan kepada organisasi kemasyarakatan yaitu pencabutan status hukum atau izin aktivitasnya sehingga dengan demikian organisasi kemasyarakatan dinyatakan bubar secara sendirinya. Tata cara pembubaran Organisasi Kemasyarakatan berdasarkan ketentuan sebelumnya dalam UndangUndang Nomor 17 Tahun 2013 tentang Organisasi Kemasyarakatan: ${ }^{21}$

1) Permohonan pembubaran Organisasi Kemasyarakatan berbadan hukum, sebagaimana disebutkan dalam pasal 68 ayat 1, diajukan ke pengadilan negeri oleh kejaksaan hanya atas permintaan tertulis dari Menteri Hukum dan HAM;

2) Permohonan tersebut diajukan kepada ketua pengadilan negeri sesuai tempat domisili hukum Organisasi

3) Kemasyarakatan dengan disertai bukti penjatuhan sanksi administratif oleh Pemerintah atau Pemerintah Daerah;

4) Dalam hal permohonan tidak disertai bukti penjatuhan sanksi administratif oleh Pemerintah atau Pemerintah Daerah, permohonan pembubaran Organisasi Kemasyarakatan berbadan hukum tidak dapat diterima;

5) Setelahnya di ajukan permohonan, pengadilan negeri menetapkan hari sidang dalam jangka waktu paling lama 5 (lima) hari kerja terhitung sejak tanggal pendaftaran permohonan;

6) Surat pemanggilan sidang pemeriksaan pertama harus sudah diterima secara patut oleh para pihak paling lambat 3 (tiga) hari sebelum pelaksanaan sidang;

7) Dalam sidang pemeriksaan Organisasi Kemasyarakatan sebagai pihak termohon diberi hak untuk membela diri dengan memberikan keterangan dan bukti di persidangan;

8) Permohonan pembubaran Organisasi Kemasyarakatan harus diputus oleh pengadilan negeri dalam jangka waktu paling lama 60 hari terhitung sejak

\footnotetext{
19 Tanjung, Purwadi, and Hartiwiningsih.

20 Tanjung, Purwadi, and Hartiwiningsih.

${ }^{21}$ Bahar Elfudllatsani, Isharyanto.
} 
tanggal permohonan dicatat dan harus diucapkan dalam sidang terbuka untuk umum. Jangka waktu ini dapat diperpanjang paling lama 20 hari atas persetujuan Ketua Mahkamah Agung;

9) Pengadilan Negeri menyampaikan salinan putusan pembubaran Organisasi Kemasyarakatan kepada pemohon, termohon, dan Menteri Hukum dan HAM dalam jangka waktu paling lama 7 (tujuh) hari terhitung Penjatuhan sanksi administrasi pembubaran Organisasi Kemasyaraktan berdasarkan Undang-Undang Nomor 17 Tahun 2013 tentang Organisasi Kemasyarakatan dapat dilihat bahwa penjatuhan sanksi administrasi dilakukan melalui putusan pengadilan yang telah memperoleh kekuatan hukum tetap, setelah itu baru pemerintah dapat menjatuhkan sanksi pencabutan status badan hukum.

Berdasarkan Undang-Undang Nomor 16 Tahun 2017 tentang Penetapan Peraturan Pemerintah Pengganti Undang-Undang Nomor 2 Tahun 2017 tentang Perubahan atas Undang-Undang Nomor 17 Tahun 2013 tentang Organisasi Kemasyarakatan, Organisasi Kemasyarakatan yang selanjutnya disebut Organisasi Kemasyarakatan adalah organisasi yang didirikan dan dibentuk oleh masyarakat secara sukarela berdasarkan kesamaan aspirasi, kehendak, kebutuhan, kepentingan, kegiatan, dan tujuan untuk berpartisipasi dalam pembangunan demi tercapainya tujuan Negara Kesatuan Republik Indonesia yang berdasarkan Pancasila dan Undang Undang Dasar Negara Republik Indonesia Tahun 1945.

Ketentuan dalam UU a quo, dijelaskan juga berkaitan dengan ajaran atau paham yang bertentangan dengan Pancasila antara lain ajaran ateisme, komunisme/marxismeleninisme, atau paham lain yang bertujuan mengganti/mengubah Pancasila dan UndangUndang Dasar Negara Republik Indonesia Tahun 1945.

Undang-Undang a quo, larangan-larangan Organisasi Kemasyarakatan sebagaimana diatur pada Pasal 59 menjelaskan sebagai berikut:

1) Menggunakan nama, lambang, bendera, atau atribut yang sama dengan nama, lambang, bendera, atau atribut lembaga pernerintahan;

2) Menggunakan dengan tanpa izin nama, lambang, bendera negara lain atau lembaga/badan internasional menjadi nama, lambang, atau bendera Organisasi Kemasyarakatan; dan/atau

3) Menggunakan nama, lambang, bendera, atau tanda gambar yang mempunyai persamaan pada pokoknya atau keseluruhannya dengan nama, lambang, bendera, atau tanda gambar Organisasi Kemasyarakatan lain atau partai politik.

4) Menerima dari atau memberikan kepada pihak manapun sumbangan dalam bentuk apapun yang bertentangan dengan ketentuan peraturan perundangundangan; dan/ atau

5) 5) Mengumpulkan dana untuk partai politik.

6) Melakukan tindakan permusuhan terhadap suku, agama, ras, atau golongan;

7) Melakukan penyalahgunaan, penistaan, atau penodaan terhadap agama yang

8) dianut di Indonesia; 
9) Melakukan tindakan kekerasan, mengganggu ketenteraman dan ketertiban umum, atau merusak fasilitas umum dan fasilitas sosial; dan/atau

10) Melakukan kegiatan yang menjadi tugas dan wewenang penegak hukum sesuai dengan ketentuan peraturan perundangundangan.

11) Menggunakan nama, lambang, bendera, atau simbol organisasi yang mempunyai persamarn pada pokoknya atau keseluruhannya dengan nama, lambang, bendera, atau simbol organisasi gerakan separatis atau organisasi terlarang;

12) Melakukan kegiatan separatis yang mengancam kedaulatan Negara Kesatuan Republik Indonesia.

Eksistensi Organisasi Kemasyarakatan (Ormas) dalam kehidupan bermasyarakat dan berbangsa merupakan bentuk komitmen negara merealisasikan kebebasan berserikat dan berkumpul yang dijamin dalam konstitusi. Negara mengharapkan Ormas dapat berpartisipasi mewujudkan tujuan dan kebijakan nasional dalam kerangka Negara Kesatuan Republik Indonesia yang berdasarkan Pancasila dan UUD 1945. Hal ini merupakan bentuk pengejawantahan nilainilai demokrasi dalam suatu negara hukum. ${ }^{22}$

Ormas dapat berperan menjadi penghubung dan pengimbang kekuatan rakyat berhadapan dengan negara, sekaligus berkontribusi positif sebagai mitra pemerintah dalam melaksanakan pembangunan dan peningkatan kesejahteraan masyarakat. Ormas dalam konteks kehidupan sosial politik juga turut andil dalam menjadi stabilitas ketertiban dan keamanan, sehingga dapat menopang kesatuan dan persatuan bangsa. ${ }^{23}$

Dengan demikian keberadaan Ormas sangatlah penting dalam penyelenggaraan negara hukum yang demokratis karena menjadi media aspirasi dan kontrol dari warga masyarakat sebagai pemilik kedaulatan terhadap pemerintah.

Dalam konteks tersebut, Pemerintah telah mengakui peran Ormas dalam penyelenggaraan negara demokratis, namun juga menekankan pentingnya penghormatan hak asasi dan kebebasan orang lain dalam menerapkan hak dan kebebasan berserikat dan berkumpul, bahkan di saat tertentu Pemerintah merasa perlu memberikan tindakan tegas kepada Ormas yang melakukan tindakan anarkis dan menganggu keamanan dan kenyamanan orang lain. Untuk itu, Pemerintah menerbitkan beberapa peraturan perundang-undangan yang mengatur terkait Ormas. Salah satunya melalui pengaturan dalam Undang-Undang No. 17 Tahun 2013 tentang Organisasi Kemasyarakatan yang memiliki alasan pembentukan sebagai respon terhadap kompleksitas dan dinamika perkembangan Ormas, sehingga memerlukan pengelolaan dan pengaturan hukum yang lebih komprehensif. ${ }^{24}$

Dalam perkembangannya, Pemerintah memperbarui aturan tersebut dengan mengeluarkan Perpu No. 2 Tahun 2017 tentang Perubahan Atas Undang-Undang No. 17 Tahun 2013 tentang Organisasi Kemasyarakatan. Alasan pembentukan pengaturan ini yaitu ditemukannya Ormas yang secara faktual terbukti memiliki asas dan kegiatan yang bertentangan dengan Pancasila dan UUD 1945.

\footnotetext{
22 Wijiatmo and Supanto.

23 Ariyanto and others.

${ }^{24}$ Bahar Elfudllatsani, Isharyanto.
} 
Pengaturan dalam Perppu ini menimbulkan polemik di masyarakat, khususnya kewenangan pembubaran Ormas berbadan hukum dilakukan langsung oleh Pemerintah, tanpa melalu mekanisme pengadilan. Keberatan disampaikan dari kumpulan Ormas yang tergabung dalam Koalisi Masyarakat Sipil mengkritik Perppu ini dengan menyatakan bahwa seharusnya proses hukum pembubaran sejak awal dilakukan melalui proses oleh lembaga yudikatif. Beberapa pakar Hukum Tata Negara salah satunya Yusril Ihza Mahendra menilai bahwa Perppu yang dikeluarkan oleh pemerintah merupakan langkah mundur dari demokrasi karena seharusnya Pemerintah tidak dapat membubarkan Ormas begitu saja, tanpa melalui mekanisme pengadilan. Beberapa pandangan ini menunjukan realitas respon masyarakat terhadap isu hukum ini.

Salah satu norma krusial yang menjadi perdebatan dalam Perppu tersebut adalah kewenangan pembubaran Ormas oleh Pemerintah sebagaimana diatur dalam Pasal 62 ayat (3) dan Pasal 80 A. Pasal 62 ayat (3) mengatur, "Dalam hal Ormas tidak mematuhi sanksi penghentian kegiatan, Menteri dan menteri yang menyelenggarakan urusan pemerintahan di bidang hukum dan hak asasi manusia sesuai dengan kewenangannya melakukan pencabutan surat keterangan terdaftar atau pencabutan status badan hukum."

Sedangkan Pasal 80A mengatur, "Pencabutan status badan hukum Ormas sebagaimana dimaksud dalam Pasal 61 ayat (1) huruf c dan ayat (3) huruf b sekaligus dinyatakan bubar berdasarkan Peraturan Pemerintah Pengganti Undang-Undang ini."

Beberapa perkara yang menguji Peppu Ormas maupun Undang-Undang Ormas Perubahan, hampir seluruhnya mempermasalahkan konstitusionalitas norma pembubaran Ormas oleh Pemerintah, khususnya pengaturan pada Pasal 62 ayat (3) dan Pasal 80A Perpu tersebut. Hal ini menunjukan bahwa isu konstitusional norma pembubaran Ormas oleh Pemerintah sangatlah berdampak dan berpengaruh kepada masyarakat, sehingga banyak Ormas dengan berbagai latar belakang mengajukan pengujian konstitusionalitas undang-undang ke Mahkamah Konstitusi. ${ }^{25}$

Terjadinya perkembangan politik hukum kewenangan pembubaran Ormas, tentunya berdampak pada pelaksaaan peraturan tersebut. Dalam praktiknya, Pemerintah menggunakan aturan ini untuk membubarkan Hizbut Tahrir Indonesia (HTI) dengan alasan bahwa fakta di lapangan menunjukan kegiatan dan aktivitasnya bertentangan dengan Pancasila dan jiwa NKRI. Atas dasar pembubaran tersebut kemudian pihak HTI mencoba menguji pencabutan tersebut melalui jalur pengadilan. Namun dalam persidangannya, Pengadilan Tata Usaha Negara (PTUN) Jakarta memutuskan bahwa Surat Keputusan Kementerian Hukum dan HAM adalah sudah sesuai dengan aturan yang sudah ditetapkan. Pihak HTI pun selanjutnya mengajukan banding ke Pengadilan Tinggi Tata Usaha Negara (PT TUN) Jakarta, namun PT TUN juga menyatakan bahwa fakta hasil pembuktian HTI terbukti mengembangan ajaran atau paham yang bertentangan dengan Pancasila dan UD 1945. Meskipun dalam jalur hukum di PTUN dan PTTUN, pengadilan menolak permohonan. ${ }^{26}$

Selain itu, catatan yang perlu diingat bahwa peristiwa pembubaran seperti ini juga pernah terjadi ketika masa orde baru tahun 1985 yaitu pembubaran terhadap Ormas

${ }^{25}$ Yatini, 'Reformulasi Konstruksi Pidana Dalam Menjerat Pelaku Tindak Pidana Korporasi', Pasca Sarjana Hukum UNS, VII (2019), 144-52.

${ }^{26}$ https://www.viva.co.id/berita/politik/91357-pancasila-dan-sejarah-pembubaran-ormas-dan-partaipolitik 
Pelajar Islam Indonesia (PII) karena Pemerintah menyatakan PII menolak menjadikan asas Pancasila menjadi asas organisasi sebagaimana diperintahkan Undang-Undang Ormas Lama, sehingga rezim Orde Baru pun membubarkan organsiasi tersebut dan menyatakannya sebagai organisasi terlarang. Dalam konteks tersebut, pelanggaran terhadap Pancasila dan UUD 1945 tentu merupakan tindakan terlarang karena mengancam keutuhan negara dan bangsa. Namun demikian, Pemerintah juga harus tetap melaksanakan kewenangan ini sesuai dengan koridor konstitusionalitas dan perspektif perlindungan hak asasi manusia dan hak kebebasan berserikat. ${ }^{27}$

\section{Analisis Putusan Pengadilan PTUN No. 211/G/2017/PTUN.JKT tentang Pembubaran Ormas HTI Dikaitkan Dengan Kebebasan Berserikat}

Putusan Pengadilan PTUN Jakarta No. 211/G/2017/PTUN.JKT tentang Pembubaran HTI jika dikaitkan dengan kebebasan berserikat adalah merupakan bentuk pelanggaran yang dilakukan oleh pemerintah terhadap warga masyarakat yang sudah dilindungi dalam UUD 1945. Namun perlu diingat, bahwa meskipun pembentukan Ormas dijamin oleh UUD 1945 bukan berarti aktivitas yang dilakukannya dapat sebebasnya. Dengan perkataan lain bahwa aktivitas ormas yang dilakukan harus senantiasa terikat kepada pembatasan untuk menghormati hak asasi dan kebebasan orang lain dalam rangka tertib hukum serta menciptakan keadilan dalam kehidupan berbangsa, dan bernegara.

Dapat dibatasinya eksistensi Ormas mengingat hak untuk bebas berserikat, berkumpul dan mengeluarkan pendapat sebagaimana diatur dalam Pasal 28E ayat (3) UUD 1945 masuk kategori hak asasi manusia yang dapat dibatasi pelaksanaannya. Berbeda dengan hak untuk hidup, hak untuk tidak disiksa, hak kemerdekaan pikiran dan hati nurani, hak beragama, hak untuk tidak diperbudak, hak untuk diakui sebagai pribadi di hadapan hukum, dan hak untuk tidak dituntut atas dasar hukum yang berlaku surut yang menurut Pasal 28I ayat (1) UUD 1945 masuk kategori hak asasi manusia yang tidak dapat dikurangi dalam keadaan apapun (non derogable rights). ${ }^{28}$

Untuk menyeimbangkan agar pelaksanaan hak kebebasan berserikat, berkumpul, dan mengeluarkan pendapat tidak mudah diberangus secara sewenang-wenang maka pembatasannya oleh negara, seperti pembubaran ormas, tetap terikat kepada kriteria tertentu. Kriteria yang dimaksud seperti yang ditetapkan dalam Pasal 28J ayat (2) UUD 1945 yaitu pembatasan ditetapkan dengan undang-undang, dilakukan dengan maksud semata-mata untuk menjamin pengakuan serta penghormatan atas hak dan kebebasan orang lain dan untuk memenuhi tuntutan yang adil sesuai dengan pertimbangan moral, nilai-nilai agama, keamanan, dan ketertiban umum dalam suatu masyarakat demokratis.

Oleh karena itu, sehubungan dengan pembubaran Ormas HTI, sesungguhnya dapat saja dilakukan sepanjang dilaksanakan dengan alasan dan melalui prosedur sebagaimana yang telah ditetapkan oleh Undang-Undang No. 17 Tahun 2013 tentang

27 Suprianto, Riwanto, and Firdaus.

28 Prasetyo Ade Witoko dan Ambar Budhisulistyawati, 'Penyelundupan Hukum Perkawianan Beda Aagama Di Indonesia', Pasca Sarjana Hukum, 7.2 (2019), 251-57. 
Ormas. Selain itu pembubaran tersebut dimaksudkan dalam rangka memastikan keamanan dan ketertiban umum dalam suatu masyarakat demokratis. ${ }^{29}$

Dalam kasus pembubaran Ormas HTI, pada dasarnya telah tedapat beberapa ratio legis (alasan hukum) yang memadai bagi Pemerintah untuk memberikan sanksi pencabutan status badan hukum atau pembubaran Ormas HTI berdasarkan putusan Pengadilan Tata Usaha Negara Jakarta No. 211/G/2017/PTUN.JKT. Hal ini mengingat Ormas HTI dianggap telah melakukan pelanggaran Undang-Undang Ormas yaitu:

a. Ormas HTI melanggar kewajiban dalam Pasal 21 huruf b yaitu ormas berkewajiban menjaga persatuan dan kesatuan bangsa serta keutuhan Negara Kesatuan Republik Indonesia. Aktivitas HTI yang di muka umum menyatakan mengusung ideologi khilafah yang berarti meniadakan NKRI jelas merupakan pelanggaran atas kewajiban ini.

b. Ormas HTI melanggar kewajiban dalam Pasal 21 huruf f yang menyebutkan bahwa Ormas berkewajiban berpartisipasi dalam pencapaian tujuan negara. Tentu saja partisipasi ini dapat tercapai jika ormas percaya kepada sistem nation state yang dipilih oleh para pendiri NKRI sejak 17 Agustus 1945. Tidak mungkin ormas yang tidak percaya dengan NKRI dan ingin menggantinya dengan sistem yang lain kemudian dapat menjalankan kewajiban berpartisipasi untuk mencapai tujuan NKRI.

c. Ormas HTI melanggar larangan dalam Pasal 59 ayat (2) huruf c yang mengatur ormas dilarang melakukan kegiatan separatis yang mengancam kedaulatan NKRI. Pengertian separatis menurut Kamus Besar Bahasa Indonesia (KBBI) adalah "orang (golongan) yang menghendaki pemisahan diri dari suatu persatuan/golongan (bangsa) untuk mendapat dukungan”. Pengertian separatis tidak harus selalu diartikan mengangkat senjata untuk memisahkan diri membentuk negara baru. Bentuk kampanye di muka umum untuk mengajak orang (masyarakat) mengganti sistem negara (NKRI) dan menggantinya dengan sistem lain yaitu khilafah pada dasarnya telah masuk kategori separatis yang mengancam kedaulatan NKRI.

Sementara mengenai penggunaan ketentuan Pasal 59 ayat (4) yang menyatakan Ormas dilarang menganut, mengembangkan, serta menyebarkan ajaran atau paham yang bertentangan dengan Pancasila agak sulit diterapkan dalam kasus HTI. Hal ini dikarenakan adanya penjelasan Pasal 59 ayat (4) yang secara limitatif telah membatasi pengertian ajaran atau paham yang bertentangan dengan Pancasila yaitu hanya meliputi ajaran ateisme, komunisme/marxisme-leninisme.

\section{CONCLUSION}

Banyak masyarakat yang bersikap skeptik kepada pemerintah berkaitan dengan Perppu No. 2 Tahun 2017 yang kemudian secara resmi menonaktifkan organisasi massa seperti Hizbut Tahrir Indonesia (HTI). Sikap tersebut muncul bersamaan dengan perasan curiga, terutama dari pihak oposisipemerintahan saat ini. Masyarakat beranggapan bahwa

${ }^{29}$ Dosen Fakultas, Hukum Universitas, and Sebelas Maret, 'POLITIK HUKUM DOKTRIN PIERCING THE CORPORATE VEIL', 181-86. 
dengan terbitnya Perppu telah mencederai proses demokrasi dengan menghubungkan pada unsur dasarnya, yaitu kemerdekaan berpikir, berhimpun, dan berekspresi. Tudingan ini serius hingga berlanjut di meja pengadilan. Dapat disimpulkan dari pernyataan tersebut bahwa walaupun pembubaran ormas HTI oleh sebagian kalangan melanggar kebebasan dalam berserikat, tetapi pemerintah juga memiliki alasan yang kuat bahwa keputusan untuk membubarkan Ormas HTI telah melalui pengkajian dan pertimbangan secara matang dengan dalih bahwa HTI telah melanggar undang undang dan hanya melahirkan perdebatan yang tidak produktif di tengah-tengah public. Alasan terakhir inilah yang mengindikasikan upaya stabilitas terhadap politik di Indonesia. Terkait dengan pembubaran Ormas HTI yang dianggap tidak sesuai dengan ideology Pancasila dan UUD 1945, maka kedepannya Pemerintah diharapkan untuk lebih selektif dalam hal pemberian ijin terhadap pendirian ormas, baik itu Ormas keagamaan ataupun bukan yang diharapkan agar kedepannya tidak bertentangan dengan UUD 1945 dan Pancasila.

\section{REFERENCES}

Achmad, Farid, 'Urgensi Penguatan Peran Penuntut Umum Dalam Sistem Peradilan Pidana Indonesia', Jurnal Pasca Sarjana Hukum UNS, VII.1 (2019), 1-14

Afreeportamara, N W, 'Hambatan Kurator Dalam Menyelesaikan Piutang Koperasi Yang Diputus Pailit', Jurnal Hukum Dan Pembangunan Ekonomi, 243-50 <https://jurnal.uns.ac.id/hpe/article/view/43014>

Ariyanto, Agung, Mahasiswa Program, Magister Ilmu, Fakultas Hukum, Universitas Sebelas, Maret Surakarta, and others, 'Politik Hukum Asas Non-Legally Binding Rekomendasi Ombudsman Republik Indonesia Sebagai Instrumen Pencegahan Dan Penanganan Laporan Maladministrasi', Jurnal Pasca Sarjana Hukum UNS, VII (2019), 62-73

Bahar Elfudllatsani, Isharyanto, Agus Riwanto, 'Kajian Mengenai Kebebasan Berkumpul Dan Berserikat Organisasi Kemasyarakatan Kaitannya Dengan Teori Kedaulatan Rakyat Dan Hak Asasi Manusia', Jurnal Pasca Sarjana Hukum UNS, VII.1 (2019), 5261

Budhisulistyawati, Prasetyo Ade Witoko dan Ambar, 'Penyelundupan Hukum Perkawianan Beda Aagama Di Indonesia’, Pasca Sarjana Hukum, 7.2 (2019), 251-57

Dica, Yulianus, Ariseno Adi, Polres Boyolali, Widodo Tresno Novianto, Dosen Fakultas, Hukum Universitas, and others, 'Pengendalian Peredaran Minuman Beralkohol Dalam Wilayah Hukum Polres Boyolali', VII (2019), 120-33

Fakultas, Dosen, Hukum Universitas, and Sebelas Maret, 'POLITIK HUKUM DOKTRIN PIERCING THE CORPORATE VEIL', 181-86

Hersriavita, Sara, 'UPAYA PENGEMBALIAN KERUGIAN NEGARA DARI PERKARA TINDAK PIDANA KORUPSI OLEH KEJAKSAAN NEGERI SUKOHARJO', Jurnal Hukum Dan Pembangunan Ekonomi, 7.1 (2019), 15-28

Mahastoro, Hernindyo Reinan, Mahasiswa Fakultas, Hukum Universitas, Sebelas Maret, Albertus Sentot Sudarwanto, Dosen Fakultas, and others, 'PERTANGGUNGJAWABAN HUKUM PENGURUS YAYASAN TERHADAP RUMAH SAKIT YANG DIKELOLA OLEH YAYASAN', VII (2019), 212-18 
Sulaksono, Satriawan, 'KORBAN TINDAK PIDANA PENCUCIAN UANG YANG TERCAMPUR DENGAN ASET PELAKU "”, 107-19

Sulistiyono, Adi, 'Majelis Kehormatan Disiplin Kedokteran Indonesia ( Mkdki ) Untuk Dapat Menjamin Keadilan Dalam Hubungan Dokter Dan Pasien', Jurnal Pasca Sarjana Hukum UNS, VII.1 (2019), 29-38

Suprianto, Agus Riwanto, and Sunny Ummul Firdaus, 'Implementasi Peraturan Pemerintah Nomor 18 Tahun 2016 Tentang Perangkat Daerah Terhadap Efektivitas Kinerja Pegawai Sekretariat Daerah Dewan Perwakilan', Jurnal Pasca Sarjana Hukum UNS, VII.1 (2019), 134-43

Tanjung, Ahmad Kodir Jailani, Hari Purwadi, and Hartiwiningsih, 'Paradigma Hakim

Dalam Memutuskan Perkara Pidana Di Indonesia', Jurnal Pasca Sarjana Hukum UNS,

7.1 (2019), 39-51 <https://jurnal.uns.ac.id/hpe/article/view/29178>

Warsito Bayu Rangga, and Albertus Sentot Sudarwanto, 'Penyelesaian Kredit Macet

Dengan Agunan Yang Diambil Alih (AYDA) Sebagai Upaya Perlindungan Kreditur

Di Perseroan Daerah BPR Bank Klaten', Jurnal Pasca Sarjana Hukum UNS, VII.2 (2019), 187-95 <https://digilib.uns.ac.id/dokumen/detail/77603/PenyelesaianKredit-Macet-dengan-Agunan-yang-Diambil-Alih-AYDA-sebagai-Upaya-

Perlindungan-Kreditur-di-Perseroan-Daerah-BPR-Bank-Klaten>

Warsito, Edi, 'Balai Konservasi Sumber Daya Alam Yogyakarta', Pasca Sarjana Hukum UNS, VII.1 (2019), 153-68 <https://jurnal.uns.ac.id/hpe/article/view/29210>

Wijiatmo, and Supanto, 'Kebijakan Hukum Pidana Dalam Memberikan Perlindungan Hukum Terhadap Guru Dalam Hal Kedisplinan', Pasca Sarjana Hukum UNS, VII No $1 \mathrm{~J}$ (2019), 85-92

Yatini, 'Reformulasi Konstruksi Pidana Dalam Menjerat Pelaku Tindak Pidana Korporasi', Pasca Sarjana Hukum UNS, VII (2019), 144-52 